\title{
Living through Transition: The Poetic Tradition of the Jbala between Orality and Literacy at a Time of Major Cultural Transformations
}

\section{Vivir en la transición: la tradición poética de Yebala entre oralidad y escritura en tiempos de grandes cambios culturales}

SARALI GINTSBURG

Institute for Culture and Society

RECIBIDO: 27 DE ABRIL DE 2020

University of Navarra

Pamplona, 31009

sgintsburg@unav.es

Orcid ID 0000-0003-2962-9534

Abstract: In my paper I analyze transformations happening in the oral tradition of the Jbala, an Arabic speaking ethnic group inhabiting the western and central part of the Rif mountains of northern Morocco. My analysis centers on the work of two modern poets, who although they see themselves belonging to the oral tradition, compose their poetry in writing. Their poetry is, therefore, characterized by use of two different, and, to some degree, opposite modes of language - the oral and the written. This is especially interesting in the context of the Arabic language, where, officially, only Standard Arabic exists in two modes - oral and written, while its dialectal varieties are seen as exclusively oral forms of communication and 'vulgar' poetry. The textual analysis will be substantiated by information received directly from both poets. To complement this analysis I examine this tradition through the lens of major cultural and identity changes occurring in local Moroccan genres and traditions at the national level and argue that the oral tradition of the Jbala is converging with the more popular and prestigious tradition of the malhun.

Keywords: Moroccan Oral Poetry. Transitional Text. Cultural Identity. Formulaic Language. Jbala. Malhun.
Resumen: Este trabajo analiza las transformaciones habidas en la tradición oral de Yebala, un grupo étnico de lengua árabe que habita la zona occidental y central de los montes del Rif en el norte de $\mathrm{Ma}-$ rruecos. Mi análisis se centra en la obra de dos poetas modernos que, aunque se ver a sí mismos como integrantes de la tradición oral, componen su poesía de forma escrita. Su poesía, por tanto, se caracteriza por el uso de dos modos lingüísticos diferentes y, en cierto grado, opuestos: el oral y el escrito. Esto resulta especialmente interesante en el contexto de la lengua árabe, donde solo el árabe estándar tiene existencia oficial en dos modos, oral y escrito, mientras que sus variedades dialectales son vistas como formas exclusivamente orales de comunicación y poesía "vulgar". El análisis textual se apoya en información recibida directamente de ambos poetas. Para completar el análisis, examino la tradición con el prisma de los grandes cambios culturales e identitarios habidos en los géneros marroquíes locales a nivel nacional y argumento que la tradición oral yebalí está convergiendo con la más popular y prestigiosa tradición del malhun.

Palabras clave: Poesía oral de Marruecos. Texto transicional. Identidad cultural. Lenguaje formular. Yebala. Malhun. 
INTRODUCTION

7 oday, right before our eyes, living poetic traditions are going through dramatic transformations. Such traditions are habitually characterized by oral, often spontaneous poetic production and belong to the public domain, in the sense that they do not have a particular author. The poetic language used in such traditions is highly canonized: it is built on poetic formulas, while poetic structure and performing mode are strictly regimented. Our emergent understanding of the oral tradition goes back to the now paradigmatic works on the epics of ancient Greek rhapsodes and Southern Slavic guslars by Milman Parry (1928) and Albert Lord (1960). Parry and Lord's findings on how oral traditions are designed and how they function, have subsequently been applied and, largely, confirmed on numerous materials from other traditions, among which are: medieval European poetry (Duggan, Fry), African (Finnegan 1977), Indian (Smith) and medieval and modern Arab poetry (Monroe, Zwettler, Alwaya, Gintsburg 2014). Today, however, when these traditions are rapidly changing, we have a good opportunity to take the research on oral traditions to the next logical stage, asking and then attempting to answer further questions, namely: how exactly are these traditions changing, what are these transformations and what is causing them?

On the one hand, the traditions are undergoing transformations caused by more consistent and frequent use of writing in the process not only of transmission but also of poetic production, thanks to which oral traditions that have until now existed exclusively in an oral mode are being written down on paper, and thus, becoming part of written literature. To this, we should also add complex geopolitical processes because, apparently, poets are being increasingly impacted by societal changes, such as urbanization, regional and national shifts of administrative power, changes in status of language and dialect spoken by poets and their audiences, etc. However interesting these changes are, they are not new - one could mention here the Livonian chronicles, Middle English verse romances, or the Lay of Hildebrand (Murray, Ford, Ayerbe). What makes the modern situation unique and worthy of research is the velocity with which changes are taking place. Various factors in today's swiftly changing world act as major catalysts for changes that otherwise might have played out over decades or even centuries, making modern oral traditions a promising field for research that might likewise shed light on unsolved mysteries of traditions that are already extinct. 
Among other things, the velocity factor enables us to reevaluate the traditionally utilitarian attitude to what is known as transitional text. Transitional texts are conventionally seen as almost useless, because although 'text' can be either oral or written, the received wisdom has long been that there should be nothing in between. Traditionally, the only use that can be made of such texts is to 'scan' them for formulas to prove their oral origin and give us a better idea of old, 'pure' oral poetry. Instead, today we are, as researchers, given a unique chance to revisit our understanding of what happens to poetic language in transition. In addition, the same factor of velocity gives us a unique opportunity to trace and analyze other processes that are affecting traditional genres today.

Nevertheless, in the framework of the present article I would like to confine the discussion to the analysis of one particular tradition, which I know fairly well, saving more general - and, therefore, more theoretical - discussion for more detailed analysis elsewhere.

Let us turn now to my material and try to follow and analyze the textual and contextual changes I outlined above in the oral tradition of the Jbala. To contextualize the material, I will first describe the general situation in Morocco as far as literacy is concerned. I will then briefly outline the general state of the art of oral traditions in Morocco and, after that, the Jebli tradition in its purely oral, pre-transitional sense. Then, I will offer my own vision of the changes that are currently happening within this tradition. Finally, to support my ideas, I will analyze the poetry of two contemporary Jebli poets. In this research I will deliberately avoid statistical data on the use of formulaic and non-formulaic language in transitional texts (see Gintsburg 2014). This present paper will therefore focus on the qualitative rather than the quantitative aspect of the question.

\section{MOROCCO: BACKGROUND ON LITERACY}

As is well-known to Arabists and linguists, the Arabic language can be roughly divided into two varieties - a Standard one, the language of fiction, newspapers, and, to some extent, television - and a Colloquial, or dialectal one. While Standard Arabic is learnt at school (be it religious or secular), Colloquial Arabic is acquired in more natural settings, i.e., at home and in the street. Although Standard Arabic has long-established fixed grammar rules, lexicon, morphology, and phonetics, Colloquial Arabic does not. Writing and, especially, speaking in Standard Arabic are quite challenging even for Arabic 
native-speakers with university degrees. In Morocco, where dialectal Moroccan Arabic is very distant from Standard Arabic, the situation is even more acute: there are numerous varieties of Moroccan Arabic, Standard Arabic and a sort of hybrid, which represents a mixture of language structures and vocabularies from Moroccan and Standard Arabic. In general, the proficiency level of Standard Arabic in Morocco is very low and many people do not master speaking it, let alone writing it.

In addition, there are numerous calls to stop using Standard Arabic entirely, instead recognizing Moroccan Arabic as an independent idiom, a status that would allow it to fill the role of the official language of the Kingdom of Morocco (Laroui). These calls point to the fact that differences between Standard Arabic and Moroccan Arabic are so dramatic that it is increasingly difficult for the native population to find a compromise between being literate - in the sense of mastering Standard Arabic - and being Moroccan. Although there have been initiatives targeted at introducing at least unified orthography norms for Moroccan Arabic, as of today, its official status remains unchanged and anyone wishing to write in Moroccan Arabic must rely on intuition rather than rules. Nevertheless, numerous written texts are simultaneously being produced in Moroccan Arabic: private correspondence increased with the beginning of the Internet era, text messages and, of course, literary work. It is now important to emphasize that writing down a poetic text in Moroccan Arabic requires knowledge of the Arabic alphabet and basic knowledge or writing and reading skills that can be attained through self-learning or attending a kuttāb, or Qur'anic school.

\section{MOROCCO: LANDSCAPE OF LIVING POETIC TRADITIONS}

The landscape of living oral traditions in Morocco represents a rich but somewhat syncretic palette, which is explained by the cultural and linguistic diversity (Gintsburg 2014). Along with unique local traditions, such as bassani (ḅassanni), abidous (ahīdūs), there exist several others, some of which are less local in character, that arguably makes them eligible to claim the status of national, or even pan-national traditions. There are two major kinds of oral tradition in Morocco: the numerous sung ones and the recited ones, the latter of which are known under the generic name of zajal. It should be noted, however, that this division is essentially relative and can be confusing at times. The sung traditions have two registers: high and low. On the high end of the scale, there are traditions like at-tarab, the medieval Andalusian musical heritage 
that dates back to the times of Moorish Spain, which is seen as the 'classy' and 'high-end' variety of the traditional music of Morocco. On the lower (i.e., more vernacular) end there are popular traditions, such as shaabi (saSbi) and malhun (malhün), although, as we shall see below, the latter term can be applied both to sung and recited genre and is therefore sometimes used interchangeably with zajal.

Interestingly, this diversity and variety seems to have a side effect: both on the national and local levels, preference for the pan-national traditions is being seen with increasing frequency, while the local ones are crystallizing around them. Traditions are thus becoming amalgamated, and they are progressively more often regarded and referred to as genre $(n \bar{u} \mathcal{S})$ and not tradition (turät). It appears that malhun is starting to play the role of the center of gravity that is attracting minor, more local traditions for the following reasons: (1) malhun is a recited/sung poetry produced either orally or in writing in a vernacular variety of Arabic language, which has existed everywhere in the Greater Maghreb, from Tunisia to Morocco, since at least the $15^{\text {th }}$ century; (2) malbun is a direct descendant of Hispano-Arabic poetry, in other words, it is strophic, prosody-based poetry and therefore not related to Classical Arabic poetry; (3) malhun has both urban and Bedouin varieties; (4) malhun has a diverse/unfixed structure, which varies not only from country to country but is subject to considerable variation within the same country; the Moroccan versions of malbun suggest using a prelude, stanzas, and at least one refrain, but this is not obligatory; (5) malhun offers a diverse rhyme pattern: aabb, abab, aaaa, etc.; (6) the length of malhun is not fixed: it ranges from one stanza to hundreds of lines; (7) in terms of topics and themes, malbun offers quite a good variety: love, praise poetry, elegy, satire, etc.

The growing popularity of malbun might also be explained by the great importance this tradition had throughout the history of Moroccan and, in a broader sense, Maghrebi literatures in general, which were conditioned by the desire to imitate the noble tradition of the Classical Arabic poetry (Fellahi/ Ijjou). In addition, the growing popularity of malbun can be explained in the broader terms of shifting identities in the context of Morocco: it is now seen not so much as a particular tradition but more as a cultural register (Magidow). All of the above necessary qualities make malbun the ideal candidate for uniting a wide array of lesser known more local genres under its umbrella.

In this connection, a couple of words must be said about shaabi, a genre that is also gaining popularity across the country. Interestingly, it does not 
seem to compete with malhun, and the two appear to co-exist independently from each other. This is probably because these two traditions - or, better to say, genres - are coming to occupy two different niches: although the shared target audience of both is the common people, shaabi is more oriented to music and dancing, while malhun appeals more to those who value poetry.

\section{JEBLI POETRY: BETWEEN ORALITY AND LITERACY}

Today the oral poetic tradition of the Jbala is represented by three different genres: ayta jebliya (Sayta jablīya), ayyu (Sayyū ) and ughniya (ughnīya). As is the case with some other traditions, division into genres is most typically contextual and has hardly anything to do with poetic language per se. In other words, it is always easy for a Jebli person to classify poetry from a particular song when he hears it performed live, but hearing the same poetry recited without musical accompaniment can cause a great deal of confusion and uncertainty, often resulting in three different people assigning the same work to the three different genres. Having already described and analyzed the above-mentioned Jebli genres in detail elsewhere (Gintsburg 2005; 2006; 2014), here, without going into too much detail, I will only mention that ughniya appears to be the newest genre, has the least rigid structure, and covers a fairly wide range of topics.

Several points must be made concerning the general characteristics of traditional Jebli poetry: it is practically always oral and, as mentioned, is almost always unauthored; in traditional Jebli culture it is very unusual to hear that someone claims authorship of one song or another. Such poetry is usually improvised but can sometimes also be memorized and then performed. Remarkably, Jebli poetry is always linked to music and performance and, perhaps because of this, is never referred to as 'poetry' or shir (sisr) or zajal (zajal). Instead, it is routinely called klam (kläm), which can be roughly compared to the meaning of English 'lyrics'. At the same time, music or Ihan (Ihan), is highly valued and, as mentioned in the previous paragraph, it is the musical accompaniment that seems to play the role of genre identifier.

A traditional Jebli poet links his/her verses to a particular melody, from the set of possible melodies, typical of this tradition. Once the melody is chosen, he/she then tries to organize his/her poetry into beyts, or quatrains. It is not clear how well the poet understands the concept of Arabic beyt and the

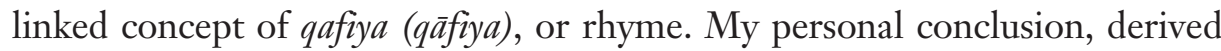
from numerous conversations with both professional and amateur local poets, 
is that they use this terminology in a rather superficial way: after all, their poems only exist when they are performed and, therefore, are difficult to visualize and compare structurally to a rather distant tradition of Classical Arabic poetry. ${ }^{1}$ However, a Jebli beyt does have particular characteristics that the poet has in mind and tries to conform with: beyt is typically but not necessarily made of four hemistichs, where each one is made of 6-8 syllables, and the second hemistich is rhymed with the fourth one. If the beyt becomes a part of ayta jebliya or ughniya, the poet will also produce a lazima (lazzima), or refrain, that will cement the text together.

Importantly, traditional Jebli poetry bears numerous markers of spontaneous composition: (1) first of all, texts are marked with excessive use of spatial and temporal deictic particles, such as (w)-ma '(and) here', '(and) now' and vocative particles $a, y a$, ayyż $h$ and $a b$ that suggest that poems are meant to be used as interaction between the poet and his/her audience/musicians; (2) to adequately understand and decipher the meaning of such poems often requires physical presence during their performance; (3) the texts of these poems are highly formulaic; (4) their rhyme is often inconsistent; (5) the number of syllables per hemistich is not always equal, a characteristic which is sometimes leveled out through a seemingly excessive use of conjunctions and vocatives, but which can also sometimes be left as it is.

To illustrate this, I offer the following examples of a traditional, oral, unauthored Jebli beyt, where markers of spontaneity are underscored: ${ }^{2}$

(1) w wsa l-xeyr Saleykum * w naSma ll la msākum And good evening to you, * And may your evening be blessed by God l-ḅaja mā̌šs $b$ al-leyl * w ma n-nadra f ujākum

Things go well in the evening.* And here, I look at your faces;

(2) ab w ma nwiwar a nwiwar * ma nwiwar $\underline{a}$ zwiwan

Ah here is a flower, flower! * Here is a beautiful flower! $\underline{\text { ma }}$ n-nās kullha b saSda * w ma diyāli ḅwiwal

Here everyone else is happy * And here my luck is non-existent!

1. Similar observations were made by Liebhaber on the material of the poetry of Mahra, where the author argues that the poetry of Mahra is 'strictly aural and is never preserved beyond the moment of performance' (Liebhaber 1409).

2. The poetic excerpts used in this article were audio recorded by the author. Their translation into English is also the author's. 
Such quatrains can still be heard on a regular basis during agricultural festivities, such as tawiza (tawiza), pilgrimages to shrines of local saints, especially, Moulay Abdessalam Ben Mshish (Gintsburg 2019c) and, sometimes, at various musical festivals.

Parallel to this, a new kind of poet and artist is starting to emerge. This is not merely because the amateur poet has become a professional, making a living exclusively by performances, since - as we know from MichauxBellaire's century-old photographically precise descriptions of practically all aspects of Jebli society - professional artists did indeed exist earlier in this tradition. Instead, this new type of poet has been engendered by the factors mentioned above, namely, more consistent and frequent use of writing, coupled with dramatic changes in the lifestyle of Jebli society, both aspects that have been amplified by the velocity factor. The artist, in his/her attempt to reflect the new reality of a society that now extends far beyond local tribal affairs increasingly begins experimenting - simultaneously endeavoring to attract a more worldly new audience without alienating the older traditional one - creating different kind of songs and, ultimately, poems. We thus now have a new generation of poetry within the tradition: authored, written texts. Authors now write down their poetry in a copy book, or kunnash (kunnäs̆), and, therefore see themselves as part of the literary Arab tradition or, perhaps more likely, part of the Magreb's centuries-old literary and music tradition. ${ }^{3}$ The very idea of using kunnās for writing down poetry for authorial purposes is associated with the genre of malhun (Pellat, 252-53), while the oral tradition of the Jbala did not know this practice. As such, it can be said that the oral tradition of the Jbala is now going through a stage of transition. What kind of changes are taking place in this tradition and what changes, if any, affect poetic production within this tradition? ${ }^{4}$ To answer these questions, let us turn to the poetic work of two contemporary Jebli poets.

3. In fact, the first Jebli poet who mentioned to me the fact that he writes down all his poems in a kunnash was Mohamed Laaroussi (1934-2014), a poet, singer and musician famous far beyond the northern Moroccan region, who is often considered by outsiders as an ambassador of the Jebli oral tradition. I did not use in this paper Laaroussi's texts because I was not able to read his kunnash and therefore, mostly worked with his performed live or recorded songs.

4. In this article I deliberately avoid the question of dictated oral texts, which I discussed elsewhere. It would be sufficient to mention in this regard that this topic represents an interesting case per se and that such texts should be seen as a variety of transitional texts, as they do differ from texts performed live (Gintsburg 2019a). 


\section{Case studies}

Below is a general analysis of poetry of two contemporary poets. Both poets whose texts I analyze in this paper are known by me personally and certain clarifications on meaning, linguistic technicalities and other important aspects, were given to me in the course of personal conversations. Both poets are well known and respected in the niche of the Jebli tradition. Interestingly, these two poets are also regularly approached by other Jebli performers and artists, who are less talented in versification, and asked to produce poetic texts. Apparently, this happens because these other performers sense their inability to produce poetry that would be well received by their audience, especially by the new generation. In what follows, I offer a review of genres and their structural organization, as well as themes and poetic diction, found in texts of both poets. However, I must admit that the simple linear division of poetry, especially when it concerns themes, is at times superficial, for one song and, hence, one poem can easily contain several themes.

\section{Case study one: Abdelmalek al-Andalussi}

Abdelmalek al-Andaloussi ( $(\mathcal{A} A$ bdalmālak l-Andalūsi), born in 1947, comes from the village Hbata $(H b \bar{a} t a)$, and the tribe Jbel Lahbib ( $f b a l l-H b \bar{\imath} b)$, but now lives in Tangier. He learned the basics of reading and writing in kuttab (kuttāb) and then he moved to Tangier, and continued self-learning. He produces most of his poems with the help of writing: for this purpose he uses kunnash, or small copybooks, that are stored, after they have been completely used up, in his office. While talking about himself, Abdelmalek reluctantly uses the word

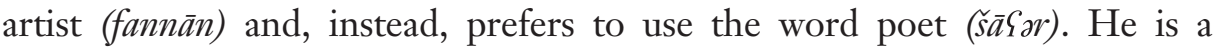
reputed poet in Jebli society and is lately being referred to as Samīd al-ughniya l-jabaliya: 'the pillar of Jebli song'. The following features characterize Abdelmalek's poetry:

a) Genres and structural organization. Abdelmalek works almost entirely in the genre of ughniya but has a couple of aytas jebliyas. Interestingly, after I had examined his aytas and found nothing in the text that would remind me of a traditional ayta, I asked Abdelmalek what makes these songs aytas and not ughniyas, and he explained that both songs are used as a sort of call to his fellow Jebli people and, sometimes, all Moroccans, or, better to say, all Muslims. When I brought to his attention the fact that many of his songs sound like a 
call, Abdelmalek quickly corrected himself by adding that it is the mode of performance and the special timing, typical of ayta, that he used for those songs that enabled him to classify them as aytas and not as ughniyas. ${ }^{5}$

By and large, Abdelmalek's poetry is highly innovative in terms of structure: he experiments freely with his poetry and often moves very far away from the 'constraints' of a traditional Jebli song. Below are some points that make his poetry sound unique, although they can still be classified as part of Jebli tradition.

In his poetry he often uses mqaddima, or a prelude, something uncommon in the non-authored traditional poetry. Mqaddima was regularly used by Mohamed Laaroussi (Gintsburg 2014), who during the later stage of his artistic career lived in Fes, which is historically considered by Jebli people to be a center of literature and vernacular poetry (Lévy-Provençal 218) and, in his own words, was influenced by the traditional poetry of Fes. Mqaddima is typically used in malhun, where the term sarrāba is used. ${ }^{6}$ The following example of such mqaddima from one of Abdelmalek poems also demonstrates that this poet can sometimes completely move away from the traditional Jebli beyt and, instead, produce a perfectly novel piece of Moroccan poetry:

(3) ya lli ḅubb al-māl

Oh, you, whose love for money,

harmak man rāhat al-bāl

Does not let you have a peace of mind!

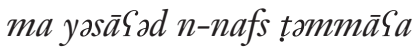

Pretentiousness does not help the soul,

geyr hubb allla wahdū

Only love for God does.

w ba qadr ma yaqwa

The stronger become

5. In addition, in the landscape of oral traditions of Morocco, ayta jebliya has a false relative, a family of various but interrelated aytas, proceeding from the central part of Morocco. Although some musicologists and ethnographers see ayta jebliya as a part of the ayta family, this is not the case (Gintsburg 2014). As I see it, the reason for this is hidden in the meaning behind this term: in Moroccan Arabic ayta means 'a call' or 'an invocation' (from the verb Sayyat - 'to cry', 'call', 'invoke'). Apparently, Abdelmalek intuitively tried to use ayta as a genre that has the potential to take the Jebli tradition out of stagnation. Please see my considerations on ughniya below for further relevant information.

6. Pellat, however, explicitly demonstrates that even within the Moroccan 'family' of malhun, prelude is not always seen as an important component of a malhun poem (Pellat 255-56). 


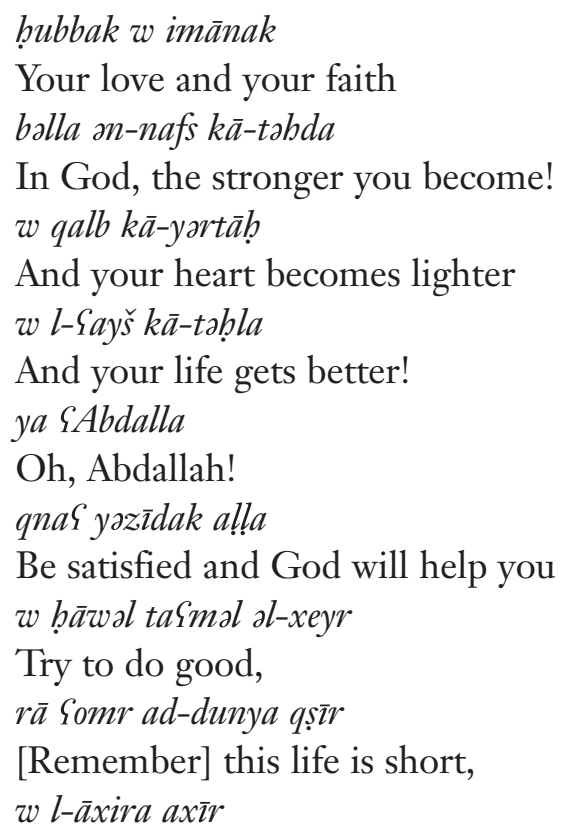

While the Afterlife will last forever.

b) Themes. The range of themes typical of Abdelmalek's poetry is, by and large, a logical continuation of the themes entrenched in the old oral tradition: social, patriotic and romantic. In this connection, what is important to note is that themes become less general and more specific. In addition, whereas a traditional poem often represents a set of themes organized in beyts, which are only distantly related to each other and require a good knowledge of the local culture, as well as the context of performance, Abdelmalek's texts are more elaborated and focused on a particular topic. However, this does not mean that they are exclusively dedicated to only one theme. Below are brief descriptions of themes that can be seen as relatively novel.

c) Didactic poetry. ${ }^{7}$ Songs that contain moral guidelines and instructions on various topics occupy an important place in Abdelmalek's poetry. To support his opinions, Abdelmalek often refers to religion and its norms, as well as his personal experiences. It is common for this poet to use a dialogic technique in

7. Interestingly, didactic literature and poetry appear to be of especial importance to nascent writers in the Islamic world (Finnegan 2012). 
such poems, as if he would like the audience to join the conversation and say something back. For instance, this can be done with the help of refrain:

(4) a xūti wahaškum w ajiz Saleya Oh, my brothers, I missed you, come along! slām alḷa Saleykom May God bring peace to you, ajiw wulla njīkum

Come along or I will come to you!

After which the poet continues:

(5) ma bqa Sabd yəxāf mūlāh * wusāx d-dunya lli Sammā

These days a servant does not fear his Master, * The dirtiness of this life has stricken him blind,

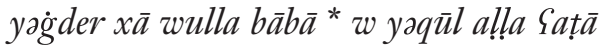
[So] he wrongs his own brother or father, * And then says: this is what God wished [for him].

d) Emigration. This topic is one of the central themes in Abdelmalek's poetry. It has a two-fold development, in fact: in a sizable portion of songs, the poet strongly advises against 'large emigration', i.e., emigration to Europe, while there are quite a few texts dedicated to the topic of what can be called 'local emigration', where Abdelmalek describes the negative consequences of leaving one's own land, the land of the free and independent people (the Jbala) and settling for some pitiful life in Moroccan towns and cities. The excerpt below gives an idea of Abdemalek's attitude toward 'large emigration' and its dangers:

(6) a xāy ya l-Sazīz

Ah, my dear brother, ya $l$-xaddām $f$ al-g̈arsa

Who is engaged in agricultural work, nənșą̧ lak ma təmši l Fransa

I advise you not to go to France!

e) Romantic poetry. Curiously, in Abdelamelek's case romantic poetry does not make an important sub-category. He does use images of women in his texts, but those images are used merely for didactic purposes. For instance, this is how al-Andaloussi portrays a typical Jebli woman in an attempt to raise the 
question of traditional values that seem to be rapidly disappearing from modern Jebli society:

(7) qwiya w șabbāra * w darbat mSāya tamāra

She is strong and patient, * Even though she has been doing hard work next to me

w bāqa f̣̣āl nuwwwāra * w Sandi mSāha $z$-žhār

She is still like a beautiful wild flower * Without her, I won't have any luck in my life!

f) Poetic diction. Interestingly, this poet, even when he refers to the themes and images typical of the Jebli oral tradition, always finds his unique way of expressing the same or, at least, a very similar idea, in a novel way. For instance, this is how al-Andaloussi remakes the theme of pilgrimage that imbues this tradition:

(8) a $l-w \bar{a} \bar{l} \bar{\imath}$ sì $l-H b \bar{\imath} b^{*}$ jìt nzürak a $l-b ̣ b \bar{\imath} b$

Oh, wali, sidi 1-Hbib, * I came to visit your shrine, my Dear, $w$ nəțlub alla yəjī $b$ * w l-faraj yəkun qrīb

And ask for God's blessings * And the healing [of the sick] is near.

As a matter of fact, it is typical for this tradition to regularly use the theme of pilgrimage, where the most popular saint is Abdessalam Ben Mshish ( $\mathcal{A} A b d$ sssalām Bən Mšišs), less common are Allal el-Hajj (SAlläl al-Hāajj) and Bushta elKhemmar (Bu Šta al-Xəmmār), while other saints from the region are mentioned only sporadically. Apparently, within this tradition, the theme of pilgrimage always implies the use of a poetic formula associated with it (there are several formulas) that allows for very limited variations. To illustrate, below are two variants of one formula often used in this context (Gintsburg 2014, 185, 192):

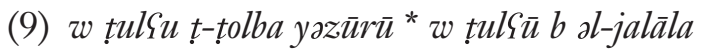

$\mathrm{Ah}$, and the religious students went to visit (his shrine), * Ah and they went extolling God w l-mūlāy SAbdəssalām * w buwa šeyx a jbāla

Ah and Moulay Abdessalam * Ah he is the patron of the Jbala

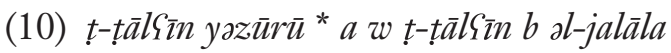

[We] are going to visit [his shrine] * Ah and we are going [there] extolling God al-ḅbīb mūlāy $S A b d$ as-Sālām * ya qand̄̄l a jbāla

[our] beloved Moulay Abdessalam * Ah the oil-lamp of the Jbala. 
Now let us return to the earlier cited poetic excerpt by Abdelmalek. It is clear that the poet has completely reformulated the theme of pilgrimage: he chose a different saint, ${ }^{8}$ and organized the beyt and the entire poem around this new character, if we can label a saint as such. In this manner, Abdelmalek preserved the traditional beyt structure but almost completely altered its contents: he only left the traditional way of addressing a saint - sĩdi wāli - and kept the idea of visiting a holy site, i.e., pilgrimage, which includes the visit, the saying of prayer (and, often, requesting help) and receipt of baraka, or blessing.?

Generally speaking, al-Andaloussi's poetry is practically non-formulaic (Gintsburg 2014). In addition, he refrains from using 'heavy' Jebli vocabulary and, instead, either sporadically uses some terminology associated with the Jbala culture and lifestyle, such as šăšiza: 'a straw hat'; qayțūna: 'a tent'. Notably, he avoids using the Jebli variety of Moroccan Arabic and, instead, uses the one that can be defined as northern variety of Moroccan Arabic.

\section{Case study two: Mohamed Gandar}

Mohamed Gandar (Mḥammad Gandār) was born in 1960, comes from the village Mwiwej (al-Mwiwaj), the tribe Bni Msawwar (Bni Msawwar), and now lives in Tangier. He learned reading and writing in kuttab and then continued self-learning. Mohamed Gandar produces most of his poetry on paper, with the exception of when he goes on a pilgrimage or spends time in his village with his family and participates in local activities, where he can occasionally engage himself in an exchange of ayyus or a sporadic performance of an ayta jebliya. When he is writing, he uses any type of paper, just to capture the ideas and rhymes. Once the poem is ready, it is copied to a kunnăs that is then stored somewhere in Mohamed's house. Mohamed Gandar is well known in the Moroccan north and participates yearly in numerous local festivals, featuring the Jebli tradition. When he describes his songs, he uses both the words lyrics (kläm) and poem (sisr). Gandar's poetry can be described in the following terms:

8. This saint is buried in the territory of the native tribe of Abdelmalek and is considered to be its patron saint. I was able to find only one poetic text referring to Sidi l-Hbib (Pereda 207): sìdi $l$ -

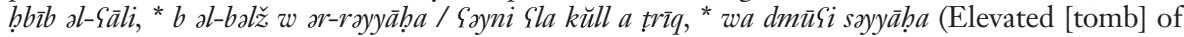
Sidi l-Hbib * It has a lock and a window; / My eyes are peering in each road * And my tears are falling).

9. For more detailed information on this rite see Gintsburg 2019c. 
a) Genres and their structural organization. Gandar works exclusively within the genre of ugbniya, which, according to his understanding, should always contain a läzima and beyts. He does not seem to favor more innovative structures and, in this regard, Gandar's poetry is less revolutionary in comparison to that of Abdelmalek. This poet, however, has moved away from the traditional Jebli concept of a poem, which does not exist without music and outside performance: he is clearly now more of a poet $(\tilde{s} \bar{a} S a r)$ and not an artist (fannān), for his poetry is now written on paper.

Generally speaking, Gandar's poetry is clearly an example of transition from a Jebli beyt with its 6-8 syllables per hemistich and spontaneous and, therefore, regularly hit-and-miss rhyming. Some of Gandar's poems maintain this pattern but they look more accurate, and we see that the poet, who now interacts with paper and, for this reason, can see his text graphically, gradually starts to adopt a different pattern:

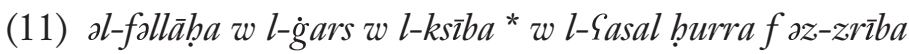
Peasant life style, plants, harvesting * And natural honey in a beehive. qayyis w duwwwaq Sala l-ḅlāwat * al-xeyr fa blādna l-ḅbība Try and taste the sweet * Wealth of our beloved land!

In this beyt and throughout the poem from which this was taken, the poet strictly follows the $a a b a$ rhyme pattern, which is rarely used by oral poets. Sometimes, he goes even further, producing a poem whose structure is so complex that it obviously suggests that the author had to come back to this text to polish it on paper:

(12) la-mra Sandha l-haqq taxdam

Woman has the right to work. w ila qrat al-qānūn $f$ al-mạ̣kama tạ̣kam

And if she studied law - let her judge in the court. w lli ma qra yatSallam

And if someone did not study - let her learn, ș-șanSa mujūda w lli bə Saqlu yatfäham

There are professions. Those, who have common sense, will understand.

b) Themes. Gandar actively uses and recycles traditional themes by giving them a more modern look. It is interesting to see how the poet takes the old theme of two lovers and a messenger who is supposed to help them to talk. 
Although traditionally in the Jebli poetry the role of messenger is played by a pigeon, and more recently, a car driver (Gintsburg 2005; 2006), Gandar intelligently introduces into his poem a mobile phone:

(13) Sayyiț li ya l-ḅbī̄ * wulla ktəo li l-misāj

Call me, ah sweetheart * Or write me a text message -

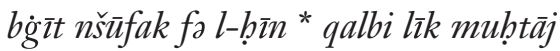

I want to see you now * My heart needs you!

Similarly to al-Andaloussi, this poet often produces didactic texts: at times he resorts to themes and motifs from the Quran and gives them a new sound, but one that is also local and easy to understand. For instance, this is how the poet interpreted one of the most basic and famous Islamic concepts - the concept of following the right path under the right guidance as one of the prerequisites of the Islamic faith (Encyclopaedia of the Quran: Patb):

(14) ya lli tālaf Sala t-trīq * ma la yə? ammen w la yatīq

Oh, the one who has gone astray: * neither does he believe in

God, nor has faith

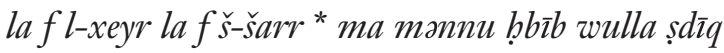

In good or bad, * He will not become a [good] relative or a friend.

In addition, Gandar also resorts to modern topics, such as women's rights (see example 12, above), and promotes the beauty, values and all kinds of advantages associated with either living or communicating with people from the Jbala area:

(15) jbāla fìhom əz-zīn * w l-hya w l-qalb ḥnīn

The Jbala are good-looking * and they are [also] humble and have a kind heart, bnāt ad-dār mqayydīn * alla yaḥfadhom man al-Sìn

[their] Girls are modest * May God protect them from evil eye!

c) Poetic diction. Linguistically, Gandar's poetic vocabulary represents the northern variety of Moroccan Arabic, just as is the case with Abdelmalek alAndalussi. Likewise, Gandar prefers not to use any specifically Jebli vocabulary, replacing it with a more neutral lexicon typical for the Tangier/Tetouan area. At the same time, in his poetic texts he sporadically uses fragments of once very popular poetic formulas that can still be recognized by his Jebli audience: 
(16) Sayyiṭ li ya l-ḅbī ${ }^{*}$ Sayyiț li mən Tațwān

Call me, ah sweetheart * Call me from Tetouan,

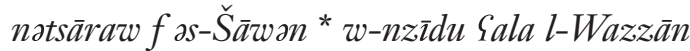

We will stroll in Chefchaouen * And then continue to Wazzan.

Now consider the following beyt from a traditional ayta: (Gintsburg 2014, 203): ${ }^{10}$

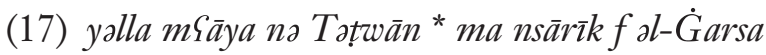

Let us go together to Tetouan! * We will stroll in Gharsa, $w n z \bar{\imath} d u$ a al-Faddān

And then continue to Feddan!11

\section{DisCUSSION}

From the analyses of poetic texts of al-Andaloussi and Gandar, it is clear that their poetry, which is now written, has acquired more regularity and stability; it is clearly no longer the product of improvised live performance: the texts lose markers of spontaneity, primarily the 'excessive' spatial and temporal deictics, vocatives and conjunctions. Instead, the poems now have highly regular rhyme and rhythm, as well as a more complex malhun-like structure, which on the formal level is manifested in regular loss of a Jebli beyt, erosion of the beyt structure in principle, as well as the regular use of a prelude.

Jebli poetry is becoming more complex and, therefore, more narrative, although it still maintains a considerable emotional component. This is also typical of malhun, where the poem is based on a narrative, although it preserves strong traces of the author's personality. Interestingly, Fellahi and Ijjou (2013) explain this polyphonic character of malhun by the inbuilt function of this genre: it is meant not only to narrate stories but also to communicate with the audience and provoke a sort of feedback. It appears that a new Jebli poet finds the nature of malhun and the requirements associated with this genre ideal: it allows him/her to: (1) narrate a story; (2) have a space for the poet's personality; and (3) maintain the dialogic and communicative nature of the Jebli oral tradition by using other language tools.

10. See other registered variations of the same formula in (Gintsburg 2014, 222).

11. Gharsa Lakbira (əl-Garsa lə-Kbīra) and Feddan (əl-Fəddān) are large squares in the historical part of Tetouan. 
Both poets have a clear preference to use ughniya over other genres within the tradition. This can be explained by the following considerations: as I mentioned elsewhere, ughniya is a relatively new genre within the tradition and it does not have rigid, i.e., stable and canonized genre requirements in terms of structure, themes or even poetic diction. Moreover, the term itself references this genre's key to success: in Moroccan Arabic, just like in any other variety, ughniya means 'song', i.e., it is simply used to draw a line between a recited text and a chanted text and is not linked to context. Furthermore, unlike the ayyu and ayta only briefly mentioned here, the Jebli ughniya is not associated specifically with Jebli culture, and can therefore be applied to any sphere of life. ${ }^{12}$

Lexically, both poets tend to use novel phrases with only sporadic insertions of traditional poetic formulas. Moreover, both poets avoid using specific Jebli vocabulary and, instead, prefer to use some sort of northern variety of Moroccan Arabic, which is easily understood in the rest of the country. This, to some degree, also tends to support the assumption that both al-Andaloussi and Gandar (and others like them) are trying to overcome the constraints of the oral tradition that is, to a large degree, linked to a context that is quickly becoming outdated. Due to the fast pace of change, this old tradition is not always able to adjust rapidly enough to remain relevant to new ways of life, and for this reason the poets have no choice but to use a new lexical base. Both alAndaloussi and Gandar deliberately go for neutral vocabulary to expand their potential audience. In this sense, malhun, again offers interesting solutions: although there has been research conducted on the poetic vocabulary of malbun, it only dealt with its old, classical varieties and does not describe the emerging ones. Consequently, by using easily intelligible modern Moroccan Arabic and organizing it in malhun-inspired poetic structures, the works of both poets can be united under the umbrella of malhun without making extreme sacrifices on the lexical level.

There are noticeable changes in the themes found in the texts of both poets: old, traditional topics are receiving less attention, while didactic poetry, as well as poetry dealing with emigration, political and economic issues and even women's rights are becoming popular, which most certainly reflects shifts in themes and topics that now preoccupy a modern Jebli, as well as non-Jebli audience. One should not forget, however, that each poet has his own person-

12. See footnote 7 for relevant discussion on the genre of ayta and its unrealized potential. 
ality and personal preferences that together with ink bleed through the paper pages of their notebooks filled with poetry. These personalities are linked to the background shared by both authors: their Jebli culture and upbringing. They, therefore, continue to draw from this well and maintain connections with the old, oral poetic tradition, making use of similar images and poetic techniques in their own poetry.

\section{CONCLUSION}

In this paper I have analyzed the character of changes currently taking place in the oral tradition of the Jbala. Such changes are happening at a very fast pace and are primarily caused by two factors: (1) consistent use of writing for poetic production, which is now replacing the oral mode, and (2) dramatic transformations within both Jebli and Moroccan society. To analyze the changes, I have elaborated a comparison between traditional oral texts and the poetry of two modern literate Jebli poets. I have thereby demonstrate exactly how the introduction of practices derived from literacy affects the process of composition and, consequently, results in a considerable elimination of certain traits typical of oral composition in performance at several levels: (1) loss of markers of spontaneity in the form of excessive use of vocative particles, conjunctions, temporal and spatial deictics; (2) levelling out of incoherent syllable and rhyme pattern; (3) transformation of the general structure of poetic text. In addition, I have shown how the tradition of the Jbala is merging with the 'mainstream' and pan-national genre of malhun; consequently, a mainstay of Jebli tradition

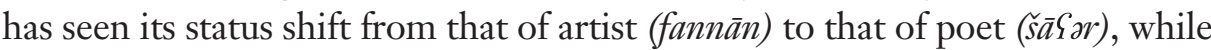
the resultant artistic production is no longer regarded as anonymous lyrics, but is now instead seen as authored poetry.

To conclude, it would be potentially interesting to apply some of the results of research of this type, i.e., research performed on living traditions, for retrospective analysis of literary works and genres of presumably oral origin, as well as entire oral traditions from earlier historical times.

\section{REFERENCES}

Alwaya, Semha. "Formulas and Themes in Contemporary Bedouin Oral Poetry". Fournal of Arabic Literature 8 (1978): 48-76.

Ayerbe Linares, Miguel. "La evolución de un mismo cantar heroico desde su transmisión oral a su transmisión escrita: el caso del Cantar de Hilde- 
brando alemán". Transitional Texts: Drifting between the Oral and the Written. Eds. S. Gintsburg, J. Ford \& A. Barandiaran. Special issue of Rilce 36.4 (2020): 1344-70.

Duggan, Joseph. The Song of Roland: Formulaic Style and Poetic Craft. Berkeley: University of California Press, 1973.

Fellahi, S., and C. Ijjou. "Le Melhun marocain: poétique, chant et musique". ScienceLib Editions Mersenne 5 (2013): 1-17.

Finnegan, Ruth. Oral literature in Africa. Cambridge: Cambridge UP, 2012.

Finnegan, Ruth. Oral poetry: its nature, significance and social context. Cambridge: Cambridge UP, 1977.

Ford, John. "Oral elements as literary skeuomorphs in the Middle English verse romances". Transitional Texts: Drifting between the Oral and the Written. Eds. S. Gintsburg, J. Ford \& A. Barandiaran. Special issue of Rilce 36.4 (2020): 1275-323.

Frolov, Dmitriy. "Path or Way". Encyclopaedia of the Qurān. Vol 4. Leiden: Brill, 2001. 28-31.

Fry, Donald. "The Cliff of Death in Old English Poetry". Comparative Research in Oral Traditions: A Memorial for Milman Parry. Ed. J. M. Foley. Columbus: Slavica, 1987. 213-34.

Gintsburg, Sarali. "Seven folk songs from the region of the Jbala". Acta Orientalia 66 (2005): 73-107.

Gintsburg, Sarali. "Some observations on the poetical language of love songs in the dialect of the Jbala". Al-Andalus-Magreb 13 (2006): 139-61.

Gintsburg, Sarali. Formulaicity in fbala Poetry (northern Morocco). Tilburg: Prisma, 2014.

Gintsburg, Sarali. "It's got some meaning but I am not sure... The role of the particle (wa)-ma in the oral and transitional poetry of the Jbala (northern Morocco) from the cognitive perspective". Pragmatics \& Cognition 24.3 (2017): 474-95.

Gintsburg, Sarali. "Lost in dictation. A cognitive approach to oral poetry: Frames, scripts and 'unnecesary' words in the Jebli ayyu". Language \& Communication 64 (2019a): 104-15.

Gintsburg, Sarali. "A Cognitive Approach to Traditional Oral Poetry: Frames and Scripts in the Jebli Ayyu". Al-Andalus Magreb 26 (2019b): 1-23.

Gintsburg, Sarali. "Identity, Place, Space, and Rhymes During a Pilgrimage to the Shrine of Moulay Abdessalam, Morocco". Fournal of Religion in Africa 48.3 (2019c): 204-30. 
Laroui, Fouad. Le Drame linguistique marocain. Casablanca: Le Fennec, 2011. Lévy-Provençal, E. "Un chant populaire religieux du Djebel marocain". Revue africaine 295 (1918): 215-48.

Liebhaber, Samuel. "Messages, Texts, and Rhetorical Detachment in Contemporary Mahri Poetry". Transitional Texts: Drifting between the Oral and the Written. Eds. S. Gintsburg, J. Ford \& A. Barandiaran. Special issue of Rilce 36.4 (2020): 1403-14.

Lord, Albert. The Singer of Tales. Cambridge, MA: Harvard UP, 1960.

Magidow, Melanie. "Trending classic: the cultural register of Moroccan Malhun poetry". The Fournal of North African Studies 21.2 (2016): 310-34.

Michaux-Belaire, Édouard. "Quelques tribus de montagnes de la region du Habt”. Archives marocaines 17 (1911): 1-11.

Monroe, James. "Oral Composition in Pre-Islamic Poetry". Fournal of Arabic Literature 3 (1972): 1-53.

Murray, Alan. "The Livonian Rhymed Chronicle as a Transitional Text Formulaic Language in Middle High German Verse History". Transitional Texts: Drifting between the Oral and the Written. Eds. S. Gintsburg, J. Ford \& A. Barandiaran. Special issue of Rilce 36.4 (2020): 1324-43.

Parry, Milman. L'Epithète traditionnelle dans Homère: essai sur un problème de style homérique. Paris: Les Belles Lettres, 1928.

Pellat, Charles. "Malhun”. Encyclopaedia of Islam. Vol. 6. Leiden: Brill, 1991. 247-57.

Pereda Roig, Carlos. Coplas de la región de Yebala, norte de Marruecos. Presentation, research, comments, glossary, and bibliography by F. Moscoso García. Barcelona: Bellaterra, 2014.

Smith, John. "Formulaic language and the epics of India". The Heroic Process: Form, Function and Fantasy in Heroic Epic. Eds. B. Almqvist, S. Ó Catháin and P. Ó Héalaí. Dun Laoghaire: Glendale Press, 1987. 591-611.

Zwettler, Michael. The Oral Tradition of Classical Arabic Poetry: Its Character and Implications. Columbus: Ohio State UP, 1978. 
Section II: Contemporary Basque 
